\title{
Oleic acid induces A7r5 cell proliferation and migration associated with increased expression of HGF and p-p38
}

\author{
JINGJING $\mathrm{LI}^{1 *}$, TING $\mathrm{CHU}^{2 *}$ and MAOSHENG YANG ${ }^{3}$ \\ Departments of ${ }^{1}$ Clinical Medicine and ${ }^{2}$ Nursing, Jishou University School of Medicine; \\ ${ }^{3}$ Laboratory of Disorders Genes and Department of Pharmacology, Jishou University \\ School of Pharmacy, Jishou, Hunan 416000, P.R. China
}

Received November 3, 2020; Accepted March 10, 2021

DOI: $10.3892 / \mathrm{mmr} .2021 .12123$

\begin{abstract}
The phenotypes and mechanisms underlying the proliferation and migration of vascular smooth muscle cells (VSMCs) induced by oleic acid (OA) are not completely understood. Therefore, the aim of the present study was to further elucidate the effects of $\mathrm{OA}$ on the proliferation and migration of VSMCs. Using A7r5 cells, the hepatocyte growth factor (HGF) inhibitor PHA665752 and the p38 MAPK inhibitor SB203580 were utilized, and Cell Counting Kit-8 (CCK-8) assays, Transwell assays, flow cytometry, ELISAs, western blotting and reverse transcription-quantitative PCR (RT-qPCR) were conducted to assess the effects of OA. CCK-8 assays indicated that OA promoted (at 5 and $50 \mu \mathrm{mol} / \mathrm{l}$ ) or inhibited (at $800 \mu \mathrm{mol} / \mathrm{l}$ ) A7r5 cell proliferation in a time- and concentration-dependent manner $(\mathrm{P}<0.05)$. Transwell assays revealed that OA also promoted (at $50 \mu \mathrm{mol} / \mathrm{l}$ ) or inhibited (at $800 \mu \mathrm{mol} / \mathrm{l}) \mathrm{A} 7 \mathrm{r} 5$ cell migration $(\mathrm{P}<0.05)$. Moreover, cell-cycle analysis identified that $50 \mu \mathrm{mol} / 1 \mathrm{OA}$ reduced the cellular population in the $\mathrm{G}_{0} / \mathrm{G}_{1}$ phase and enhanced the cellular population in the $\mathrm{S}$ phase $(\mathrm{P}<0.05)$, whereas $800 \mu \mathrm{mol} / \mathrm{l} \mathrm{OA}$ increased the cell number in the $\mathrm{G}_{0} / \mathrm{G}_{1}$ phase and decreased the cell number in the $\mathrm{S}$ phase $(\mathrm{P}<0.05)$. In addition, OA promoted (at $50 \mu \mathrm{mol} / \mathrm{l}$ ) or inhibited (at $800 \mu \mathrm{mol} / \mathrm{l}$ ) the expression level of HGF in A7r5 cells, as demonstrated via ELISA, western
\end{abstract}

Correspondence to: Professor Maosheng Yang, Laboratory of Disorders Genes and Department of Pharmacology, Jishou University School of Pharmacy, Staff Building No. 55, 120 Renmin South Road, Jishou, Hunan 416000, P.R. China

E-mail: yangmaosheng@hotmail.com

${ }^{*}$ Contributed equally

Abbreviations: CCK-8, Cell Counting Kit-8; CVD, cardiovascular diseases; FAs, fatty acids; HGF, hepatocyte growth factor; HTG, hypertriglyceridemia; OA, oleic acid; p-p38, phosphorylated p38; RT-qPCR, reverse transcription-quantitative PCR; ROS, reactive oxygen species; TG, triglyceride; VSMCs, vascular smooth muscle cells

Key words: OA, VSMCs, proliferation, migration, HGF, p-p38 blotting and RT-qPCR analyses $(\mathrm{P}<0.05)$. It was also found that OA promoted (at $50 \mu \mathrm{mol} / \mathrm{l}$ ) or inhibited (at $800 \mu \mathrm{mol} / \mathrm{l}$ ) the expression level of phosphorylated (p)-p38 in A7r5 cells, as indicated by western blotting $(\mathrm{P}<0.05)$. Furthermore, the cell proliferation, migration and HGF expression induced by OA $(50 \mu \mathrm{mol} / \mathrm{l})$ were mitigated by treatment with PHA665752 $(0.1 \mu \mathrm{mol} / \mathrm{l})(\mathrm{P}<0.05)$, and the cell proliferation, migration and p-p38 expression induced by OA $(50 \mu \mathrm{mol} / \mathrm{l})$ were mitigated by SB203580 $(2 \mu \mathrm{mol} / \mathrm{l})(\mathrm{P}<0.05)$. Thus, the results suggested that OA served a role in the proliferation and migration of VSMCs via HGF and the p38 MAPK pathway. Moreover, the proliferation and migration of VSMCs induced by OA was associated with increased expression levels of HGF and p-p38. Taken together, OA, HGF and p38 MAPK may be potential therapeutic targets for the treatment of atherosclerosis.

\section{Introduction}

Hypertriglyceridemia (HTG) refers to serum triglyceride (TG) levels at $\geq 150 \mathrm{mg} / \mathrm{dl}$ or $\geq 1.7 \mathrm{mmol} / 1$, and its prevalence increases with age (1). Previous studies have reported that HTG is one of the risk factors for numerous cardiovascular diseases (CVD) $(2,3)$. Glycerin and fatty acids (FAs) are common metabolites of TGs, and serve a role in energy metabolism and maintaining physiological functions in multiple organisms $(4,5)$. However, the effects and mechanisms of TGs or how their metabolites alter the structure and function of vascular smooth muscle cells (VSMCs) require further investigation.

The abnormal proliferation and migration of VSMCs is one of the characteristics of atherosclerosis (6-8). Zhou et al (9) revealed that high TG serum levels could stimulate the proliferation of human fetal VSMCs and affect the ultrastructure of cells, but results from Yin et al (10) suggested that high TG serum levels did not significantly promote the proliferation of VSMCs. Furthermore, Mattern and Hardin (11) reported that oleic acid (OA) could reduce the apoptosis of VSMCs induced by palmitic acid. Our previous studies indicated that triolein (12) and medium-chain TGs (13) can promote (at low concentrations) or inhibit (at high concentrations) the proliferation of rat aortic VSMCs in a time- and concentration-dependent manner.

OA, a monounsaturated FA, representing $\sim 80 \%$ of plasma phospholipid monounsaturated FAs, is one of the primary FA 
components of the Mediterranean diet and olive oil, is involved in the regulation of cell proliferation $(14,15)$. Moreover, it is one of the metabolites derived from TGs (15). However, the effects and mechanisms via which OAs regulate cell proliferation remain to be elucidated.

Hepatocyte growth factor (HGF) is a cytokine with multiple biological effects, such as promoting cell survival and the regeneration of tissues, and suppressing and improving chronic inflammation and fibrosis (16), and serves a role in promoting or inhibiting cell proliferation (17). However, to the best of our knowledge, whether the HGF signaling pathway is involved in the OA-induced proliferation of VSMCs is largely unknown, and this issue was first discussed by Greene et al (18).

MAPK is a key signaling pathway that regulates cell proliferation, apoptosis, inflammatory responses and differentiation by activating a series of downstream regulatory factors $(19,20)$. The MAPK family includes the JNK and p38 families $(21,22)$. Furthermore, p38 MAPK signaling is closely associated with atherosclerosis, as it has been demonstrated to serve a role in VSMC (23) and H441 cell proliferation (24), HGF secretion (25) and connexin 43 expression (26).

Therefore, the main aim of the present study was to elucidate the relationship between the effect of OA on VSMCs and the HGF and p38 MAPK-signaling pathways.

\section{Materials and methods}

Reagents. High glucose $(25 \mathrm{mmol} / \mathrm{l})$ DMEM was purchased from Gibco (Thermo Fisher Scientific, Inc.). OA was purchased from the Cayman Chemical Company. Cell Counting Kit-8 (CCK-8) assays were purchased from the Beyotime Institute of Biotechnology, while PI was purchased from Sigma-Aldrich (Merck KGaA). Commercial HGF ELISA kit (cat. no. EK1301) was purchased from Boster Biological Technology. RevertAid First Strand cDNA Synthesis kits were purchased from Hangzhou Woosen Biotechnology Co., Ltd., and SYBR Green quantitative PCR (qPCR) mix for reverse transcription-qPCR (RT-qPCR) was purchased from Takara Biotechnology Co., Ltd. Transwell chambers were obtained from Corning, Inc. Rabbit anti-human polyclonal antibody against HGF (cat. no. ab83760) was purchased from Abcam, p38 (cat. no. AM8123) and phosphorylated p38 (p-p38; cat. no. AM1195) antibodies were obtained from Hunan Auragene Biotechnology Co., Ltd., and monoclonal antibodies against GAPDH (cat. no. 8884) were purchased from Cell Signaling Technology, Inc. The PVDF membrane and ECL detection kits were obtained from EMD Millipore. Goat anti-rabbit (cat. no. SA009) and mouse (cat. no. SA001) IgG secondary antibodies conjugated to HRP, the BCA protein assay kit, DMSO, SDS-PAGE loading buffer, TRIzol ${ }^{\circledR}$ reagent and RIPA buffer were obtained from Hunan Auragene Biotechnology Co., Ltd. Penicillin and streptomycin were purchased from MP Biomedicals, LLC. The HGF inhibitor PHA665752 (27) and the p38 MAPK inhibitor SB203580 were obtained from Selleck Chemicals.

Cell line and culture. A7r5 cells, a smooth muscle cell line derived from the rat thoracic aorta, were obtained from The Cell Bank of Type Culture Collection of the Chinese Academy of Sciences. Cells were cultured in high glucose
(25 mmol/l) DMEM supplemented with 10\% FBS (Hunan Auragene Biotechnology Co., Ltd.) (28), $100 \mathrm{U} / \mathrm{ml}$ penicillin and $100 \mathrm{mg} / \mathrm{ml}$ streptomycin in a humidified atmosphere of $5 \% \mathrm{CO}_{2}$ at $37^{\circ} \mathrm{C}$.

Cell proliferation assays. A7r5 cells were seeded in a 96-well tissue culture plate at a density $5 \times 10^{3}$ cells/well. DMSO (50 mmol/l) was used as a solvent to dissolve OA. The final concentration of DMSO in all experimental groups was not $>1 \mathrm{mmol} / \mathrm{l}(<0.1 \%)(29,30)$. Several studies have suggested that treatment with $1-25 \mu \mathrm{M}$ SB203580 $(31,32)$ and $0.1 \mu \mathrm{mol} / 1$ PHA665752 $(30,33,34)$ does not induce cell death and does not reduce the number of cells cultured. Thus, these cells were then incubated at $37^{\circ} \mathrm{C}$ with different concentrations of $\mathrm{OA}(0$, $0.5,5,50,200$ or $800 \mu \mathrm{mol} / \mathrm{l}$ ) for 24 and $48 \mathrm{~h}$, or $0 \mu \mathrm{mol} / 1$ OA, $50 \mu \mathrm{mol} / 1 \mathrm{OA}, 50 \mu \mathrm{mol} / 1 \mathrm{OA}+0.1 \mu \mathrm{mol} / 1 \mathrm{PHA} 665752$ or $50 \mu \mathrm{mol} / 1 \mathrm{OA}+2 \mu \mathrm{mol} / 1 \mathrm{SB} 203580$ for $24 \mathrm{~h}$. Concentrations of 0.1 and $2.0 \mu \mathrm{mol} / 1$ represented the $\mathrm{IC}_{50}$ of PHA665752 and SB203580, respectively. Moreover, $0 \mu \mathrm{mol} / 1 \mathrm{OA}$ (containing $1 \mathrm{mmol} / \mathrm{l} \mathrm{DMSO}$ ) served as a control. After treatment, the medium was removed from the wells, and $0.1 \mathrm{ml}$ high glucose DMEM containing 10\% CCK-8 was added to each well for $3 \mathrm{~h}$ at $37^{\circ} \mathrm{C}$ according to the manufacturer's instructions. Cell viability was determined by measuring the absorbance at $450 \mathrm{~nm}$ using averages from quintuplicate wells, and normalized to a control well. The absorbance at each time point was determined using a microplate reader. All experiments were performed $\geq 3$ times.

Cell cycle analysis. A7r5 cells were seeded in a 6-well tissue culture plate at a density $2.5 \times 10^{5}$ cells/well. These cells were then incubated at $37^{\circ} \mathrm{C}$ with three different concentrations of OA $(0,50$ or $800 \mu \mathrm{mol} / 1)$ for $24 \mathrm{~h} ; 0 \mu \mathrm{mol} / 1 \mathrm{OA}$ (containing $1 \mathrm{mmol} / 1 \mathrm{DMSO})$ served as a control. After treatment, cells were harvested using trypsin. The cells were centrifuged at $300 \mathrm{x}$ g for $5 \mathrm{~min}$ at $25^{\circ} \mathrm{C}$, washed twice with cold PBS and fixed with $75 \%$ cool ethanol at $-20^{\circ} \mathrm{C}$ overnight (not $<16 \mathrm{~h}$ ). The fixed cells were then centrifuged at $200 \mathrm{x}$ g for $5 \mathrm{~min}$ at $25^{\circ} \mathrm{C}$ and washed twice with cold PBS. Then, cells were stained with $50 \mu \mathrm{g} / \mathrm{ml}$ PI containing $10 \mu \mathrm{g} / \mathrm{ml}$ RNase A for $30 \mathrm{~min}$ on ice. Finally, the distributions of cells in different cell cycle phases were assessed using specific amounts of cellular DNA ( $2 \times 10^{5}$ cells/tube) and flow cytometry (CytoFLEX; Beckman Coulter, Inc.). In total, $>10,000$ cells were counted per sample, and DNA histograms for cell cycle analysis were analyzed using Cell Quest software version 2.0 (BD Biosciences). The percentage of cells in the $G_{0} / G_{1}$ phase, $S$ phase and $G_{2} / M$ phase were analyzed, and all experiments were repeated in triplicate.

Transwell assays. A7r5 cells in logarithmic growth phase were harvested with trypsin, and then starved in serum-free medium. Next, a cell suspension $\left(2 \times 10^{4}\right.$ cells $)$ in $0.3 \mathrm{ml}$ high-glucose DMEM was seeded into the upper well of a Transwell chamber $\left(0.33 \mathrm{~cm}^{2}\right.$ growth surface area; 8 -pm pore size), and these cells were then treated at $37^{\circ} \mathrm{C}$ with three concentrations of $\mathrm{OA}$ $(0,50$ or $800 \mu \mathrm{mol} / 1)$, or $0 \mu \mathrm{mol} / 1 \mathrm{OA}, 50 \mu \mathrm{mol} / 1 \mathrm{OA}, 50 \mu \mathrm{mol} / 1$ $\mathrm{OA}+0.1 \mu \mathrm{mol} / 1 \mathrm{PHA} 665752$ and $50 \mu \mathrm{mol} / 1 \mathrm{OA}+2 \mu \mathrm{mol} / 1$ SB203580 for $24 \mathrm{~h}$. Moreover, $0 \mu \mathrm{mol} / \mathrm{l}$ OA (containing $1 \mathrm{mmol} / 1 \mathrm{DMSO})$ served as a control. In the lower chamber, $0.5 \mathrm{ml}$ high-glucose DMEM with $10 \%$ FBS was added. After 
incubation for $24 \mathrm{~h}$ at $37^{\circ} \mathrm{C}$ in a humidified incubator with $5 \% \mathrm{CO}_{2}$, the cells on the upper side of the upper chamber were removed using a cotton swab. The lower side of the upper chamber was fixed with $3 \%$ methanol for $5 \mathrm{~min}$ at $25^{\circ} \mathrm{C}$, and stained with $2 \%$ crystal violet for $10 \mathrm{~min}$ at $25^{\circ} \mathrm{C}$. The number of cells penetrating across the membrane was counted using an inverted microscope at x100 magnification in three random visual fields, and all experiments were performed in triplicate.

HGF level analysis using ELISA. After stimulation at $37^{\circ} \mathrm{C}$ with three different concentrations of OA $(0,50$ or $800 \mu \mathrm{mol} / \mathrm{l})$ for $24 \mathrm{~h}, \mathrm{~A} 7 \mathrm{r} 5$ cells $\left(1 \times 10^{6}\right.$ cells) were collected and centrifuged at $1,000 \mathrm{xg}$ for $10 \mathrm{~min}$ at $25^{\circ} \mathrm{C}$ to remove debris. The $0 \mu \mathrm{mol} / 1$ OA (containing $1 \mathrm{mmol} / 1 \mathrm{DMSO}$ ) served as a control. HGF protein levels in these cells were quantified using an ELISA kit (Abcam), according to the manufacturer's instructions, and all samples were measured three times. All experiments were repeated $\geq 3$ times.

Western blotting. After stimulation at $37^{\circ} \mathrm{C}$ with three different concentrations of OA $(0,50$ or $800 \mu \mathrm{mol} / 1)$, or $0 \mu \mathrm{mol} / 1 \mathrm{OA}$, $50 \mu \mathrm{mol} / 1 \mathrm{OA}, 50 \mu \mathrm{mol} / 1 \mathrm{OA}+0.1 \mu \mathrm{mol} / 1 \mathrm{PHA} 665752$ and $50 \mu \mathrm{mol} / 1 \mathrm{OA}+2 \mu \mathrm{mol} / 1 \mathrm{SB} 203580$ for $24 \mathrm{~h}$, cells $\left(1 \times 10^{6}\right.$ cells) were washed with PBS and then lysed in RIPA buffer for $30 \mathrm{~min}$ at $4^{\circ} \mathrm{C}$. The $0 \mu \mathrm{mol} / 1 \mathrm{OA}$ (containing $1 \mathrm{mmol} / 1 \mathrm{DMSO}$ ) served as a control. The total protein concentrations were measured using a BCA protein assay kit. Equal amounts of protein (20 $\mu \mathrm{g} /$ well) were then mixed with SDS-PAGE loading buffer and boiled for $10 \mathrm{~min}$. These samples were separated using $12 \%$ SDS-PAGE, and then transferred to a PVDF membrane. Membranes were incubated with appropriate concentration of primary antibody for HGF (1:100 dilution), p38 (1:1,000 dilution), p-p38 (1:1,000 dilution) or GAPDH (1:1,000 dilution) overnight at $4^{\circ} \mathrm{C}$. After washing three times with $1 \mathrm{X}$ TBS- $0.1 \%$ Tween 20, these membranes were incubated for $1 \mathrm{~h}$ with goat anti-rabbit or anti-mouse IgG secondary antibodies (1:15,000 dilution) conjugated to HRP for evaluating the expression levels of HGF and GAPDH. Proteins were visualized using an ECL detection kit, and the relative band intensities were analyzed using Image Pro Plus 6.0 software (Media Cybernetics, Inc.). All results were verified using $\geq 3$ independent experiments.

$R N A$ isolation, $R T$ and $R T-q P C R$. Total RNA was isolated from $\mathrm{A} 7 \mathrm{r} 5$ cells $\left(1 \times 10^{6}\right.$ cells), after stimulation at $37^{\circ} \mathrm{C}$ with varying concentrations of $\mathrm{OA}(0 \mu \mathrm{mol} / 1 \mathrm{OA}, 50 \mu \mathrm{mol} / 1 \mathrm{OA}$ and $50 \mu \mathrm{mol} / 1 \mathrm{OA}+0.1 \mu \mathrm{mol} / 1 \mathrm{PHA} 665752)$ for $24 \mathrm{~h}$, using TRIzol reagent, according to the manufacturer's instructions. The $0 \mu \mathrm{mol} / \mathrm{l}$ OA (containing $1 \mathrm{mmol} / \mathrm{l} \mathrm{DMSO}$ ) served as a control. cDNAs were synthesized using $1 \mu \mathrm{g}$ total RNA with the RevertAid First Strand cDNA Synthesis kit, following the manufacturer's instructions. RT-qPCR was performed using SYBR Green qPCR mix, following the manufacturer's instructions. The $\beta$-actin gene was measured as an internal quantitative control. All reactions were carried out on an $\mathrm{ABI}^{\circledR}$ 7300 Real-Time PCR system (Applied Biosystems; Thermo Fisher Scientific, Inc.) in duplicate. The reaction conditions were as follows: Initial denaturation at $95^{\circ} \mathrm{C}$ for $3 \mathrm{~min}$; followed by 40 cycles of denaturation at $95^{\circ} \mathrm{C}$ for $10 \mathrm{sec}$, annealing and elongation at $60^{\circ} \mathrm{C}$ for $10 \mathrm{sec}$; and final extension at $72^{\circ} \mathrm{C}$ for $30 \mathrm{sec}$. Melt curves were analyzed for each sample. The average value in each duplicate was used to calculate the relative amount of HGF using the $2^{-\Delta \Delta \mathrm{Cq}}$ method (35). The primer sequences were as follows: HGF forward, 5'-TCATTGGTA AAGGAGGCA-3' and reverse, 5'-GTCACAGACTTCGTA GCG-3'; and $\beta$-actin forward, 5'-AGGCCCCTCTGAACC CTAAG-3' and reverse, 5'-CCAGAGGCATACAGGGAC AAC-3'. All experiments were conducted $\geq 3$ times.

Statistical analysis. Data are presented as the mean \pm SD. All statistical analyses were performed using SPSS 20.0 software (IBM Corp.). Differences between two groups were compared using a two-tailed Student's t-test, and the one-way ANOVA followed by Tukey's test was performed to compare data between multiple groups. $\mathrm{P}<0.05$ was considered to indicate a statistically significant difference.

\section{Results}

Effects of $O A$ on A7r5 cell proliferation and migration. First, A7r5 cells were treated with increasing concentrations of OA $(0,0.5,5,50,200$ and $800 \mu \mathrm{mol} / \mathrm{l})$. Then, CCK-8 assays were conducted to evaluate the cell viability at two time points (24 and $48 \mathrm{~h}$ post-treatment), based on findings from previous studies $(12,13)$. The current results demonstrated that OA treatment promoted A7r5 cell proliferation at lower concentrations (5 and $50 \mu \mathrm{mol} / \mathrm{l})$, but inhibited A7r5 cell proliferation at higher concentrations $(800 \mu \mathrm{mol} / \mathrm{l})$, in a time- and concentration-dependent manner (Fig. 1A). The optimal parameters for promoting cell proliferation were determined to be $24 \mathrm{~h}$ and a dose of $50 \mu \mathrm{mol} / \mathrm{l} \mathrm{OA}$. According to the aforementioned results, three concentrations of OA $(0,50$ and $800 \mu \mathrm{mol} / \mathrm{l})$ and the treatment period of $24 \mathrm{~h}$, were selected for subsequent experiments. Treatment with $0 \mu \mathrm{mol} / 1 \mathrm{OA}$ (containing $1 \mathrm{mmol} / \mathrm{l} \mathrm{DMSO})$ served as a control group.

Next, A7r5 cells were incubated with three different OA conditions $(0 \mu \mathrm{mol} / 1 \mathrm{OA}, 50 \mu \mathrm{mol} / 1 \mathrm{OA}$ or $50 \mu \mathrm{mol} / 1+$ $0.1 \mu \mathrm{mol} / 1 \mathrm{PHA} 665752)$ for $24 \mathrm{~h}$. The data indicated that the effect of OA (at $50 \mu \mathrm{mol} / \mathrm{l}$ ) in promoting cell proliferation was mitigated by PHA665752 (0.1 $\mu \mathrm{mol} / \mathrm{l})$ (Fig. 1B). Subsequently, A7r5 cells were treated with three different concentrations of OA $(0,50$ and $800 \mu \mathrm{mol} / \mathrm{l})$ for $24 \mathrm{~h}$. Compared with the $0 \mu \mathrm{mol} / \mathrm{l}$ OA group $\left(\mathrm{G}_{0} / \mathrm{G}_{1}\right.$ phase, $65.72 \pm 1 \%$; $\mathrm{S}$ phase, $\left.25.31 \pm 0.3 \%\right)$, the results of flow cytometry demonstrated that low concentrations of OA (at $50 \mu \mathrm{mol} / \mathrm{l}$ ) reduced the number of cells in the $\mathrm{G}_{0} / \mathrm{G}_{1}$ phase $(56.06 \pm 1.6 \%)$ and increased the number of cells in the $\mathrm{S}$ phase $(33.71 \pm 0.9 \%)$, while high concentrations of $\mathrm{OA}$ (at $800 \mu \mathrm{mol} / \mathrm{l}$ ) increased the number of cells in the $\mathrm{G}_{0} / \mathrm{G}_{1}$ phase $(73.64 \pm 1.1 \%)$ and decreased the number of cells in the $S$ phase (16.52 $\pm 0.7 \%)$ (Fig. 1C).

Transwell assay results indicated that low concentrations of OA (at $50 \mu \mathrm{mol} / \mathrm{l}$ ) promoted cell migration, but high concentrations of OA (at $800 \mu \mathrm{mol} / \mathrm{l}$ ) suppressed cell migration (Fig. 1D). Additionally, when A7r5 cells were incubated with $0 \mu \mathrm{mol} / 1 \mathrm{OA}, 50 \mu \mathrm{mol} / 1 \mathrm{OA}$ or $50 \mu \mathrm{mol} / 1 \mathrm{OA}+0.1 \mu \mathrm{mol} / 1$ PHA665752 for $24 \mathrm{~h}$, the results suggested that the effect of OA (at $50 \mu \mathrm{mol} / \mathrm{l}$ ) in promoting cell migration was mitigated by treatment with PHA665752 (0.1 $\mu \mathrm{mol} / \mathrm{l})$ (Fig. 1E).

Effects of OA on HGF expression in A7r5 cells. OA treatment increased HGF expression at low concentrations 
A

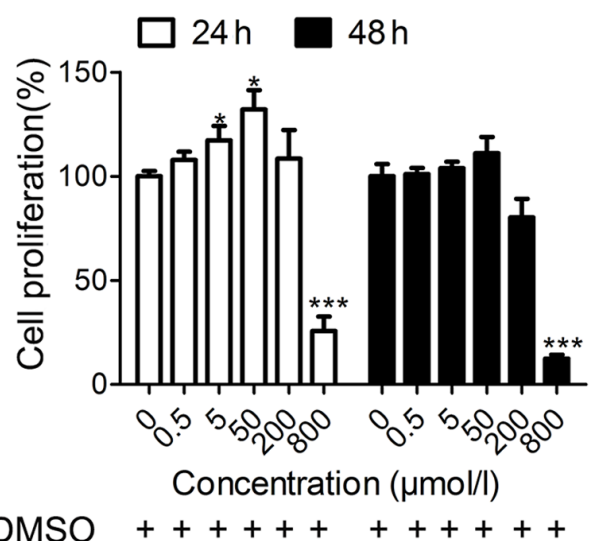

C
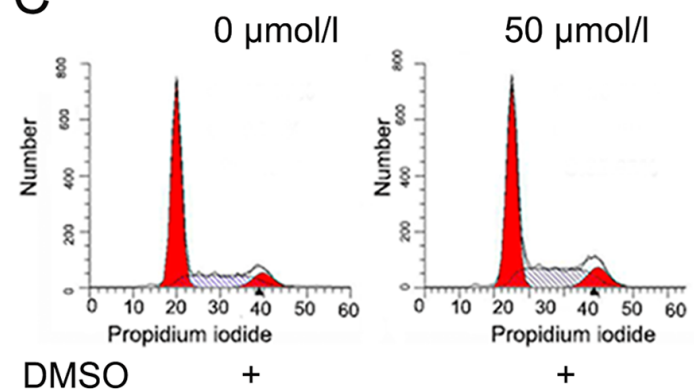

$+$
B

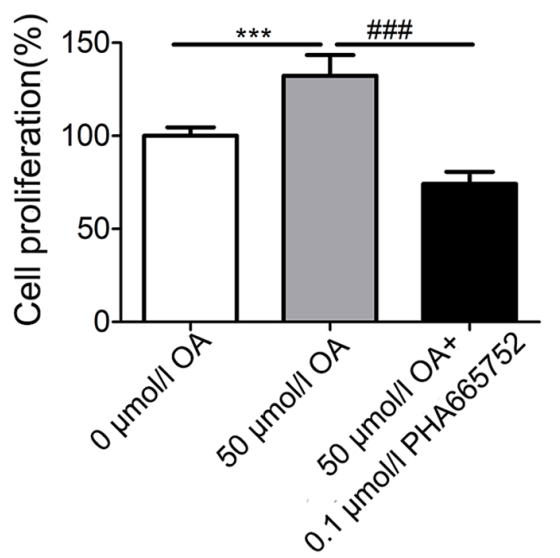

$\mathrm{D}$

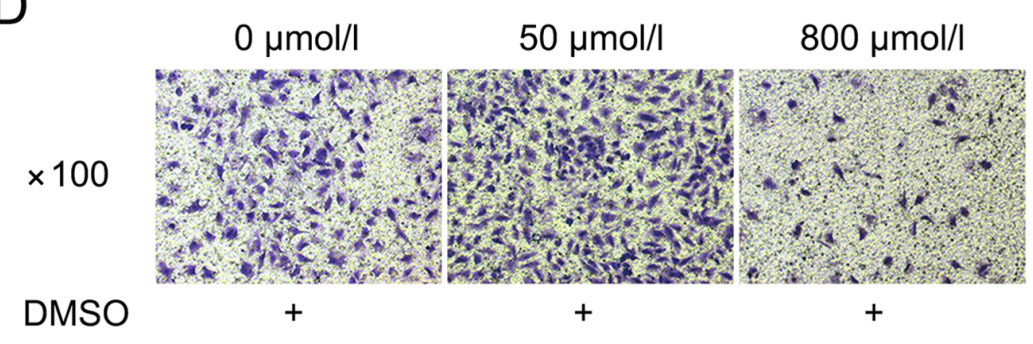

$E$

$\times 100$

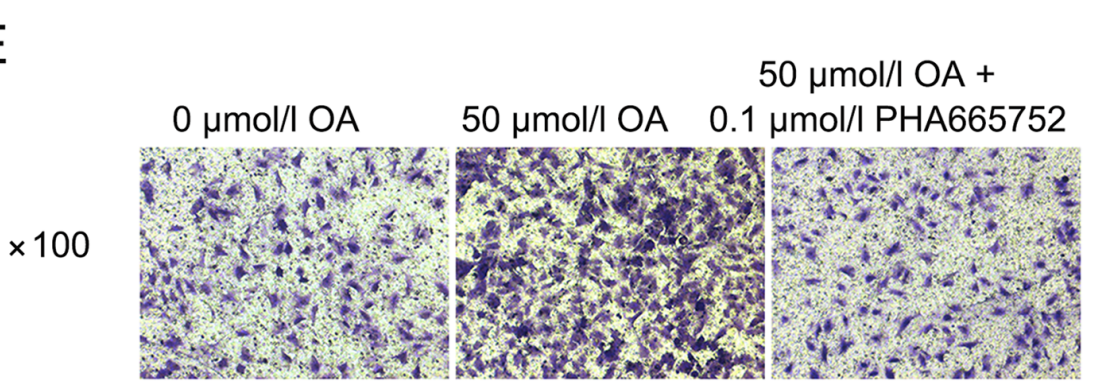

$800 \mu \mathrm{mol} / \mathrm{l}$

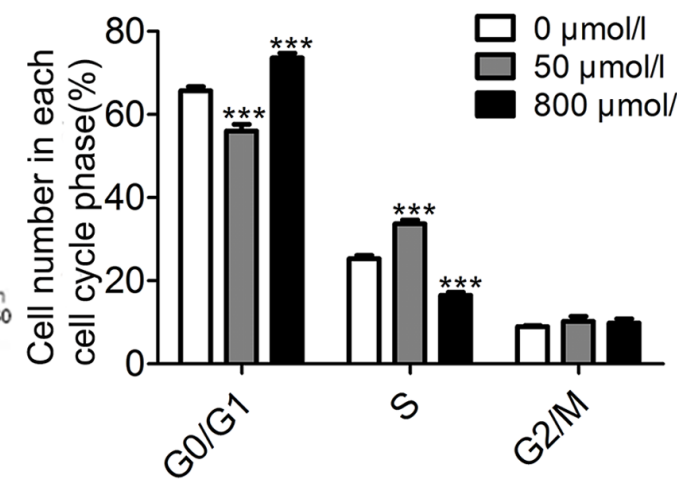

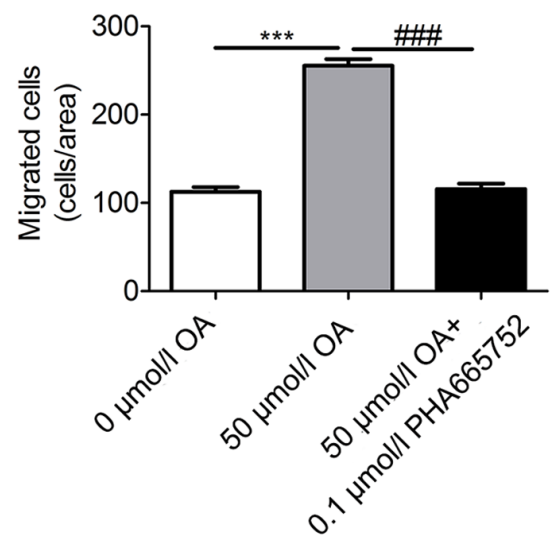

Figure 1. Effect of OA on the proliferation, migration and cell cycle of A7r5 cells. (A) Cell Counting Kit-8 assays showed that OA significantly promoted (at 5 and $50 \mu \mathrm{mol} / 1$ ) or inhibited (at $800 \mu \mathrm{mol} / 1$ ) A7r5 cell proliferation in a time- and concentration-dependent manner at 24 and $48 \mathrm{~h}$. (B) Optimal effect of $50 \mu \mathrm{mol} / 1 \mathrm{OA}$ for $24 \mathrm{~h}$ on cell proliferation was mitigated by $0.1 \mu \mathrm{mol} / 1 \mathrm{PHA} 665752$, which is a selective inhibitor of HGF. (C) Flow cytometry assays at $24 \mathrm{~h}$ identified that low concentrations of OA $(50 \mu \mathrm{mol} / 1)$ reduced the number of cells in the $\mathrm{G}_{0} / \mathrm{G}_{1}$ phase and increased the number of cells in the $\mathrm{S}$ phase. However, high concentrations of $\mathrm{OA}(800 \mu \mathrm{mol} / \mathrm{l})$ increased the number of cells in $\mathrm{G}_{0} / \mathrm{G}_{1}$ phase and decreased the number of cells in $\mathrm{S}$ phase. (D) Transwell assays at $24 \mathrm{~h}$ demonstrated that $\mathrm{OA}$ at low concentrations $(50 \mu \mathrm{mol} / \mathrm{l})$ promoted cell migration, but a high concentration $(800 \mu \mathrm{mol} / \mathrm{l})$ suppressed migration. (E) OA $(50 \mu \mathrm{mol} / 1)$ promoted cell migration at $24 \mathrm{~h}$, which was mitigated by PHA665752 ( $0.1 \mu \mathrm{mol} / \mathrm{l})$. Data are presented as the mean \pm SD $(\mathrm{n}=3)$. Magnification, $\mathrm{x} 100$. ${ }^{*} \mathrm{P}<0.05,{ }^{* * *} \mathrm{P}<0.01$ and ${ }^{* * *} \mathrm{P}<0.001$ vs. $0 \mu \mathrm{M}$ OA group; ${ }^{\sharp \# \#} \mathrm{P}<0.001$ vs. $50 \mu \mathrm{mol} / 1 \mathrm{OA}$ group. OA, oleic acid. 
A

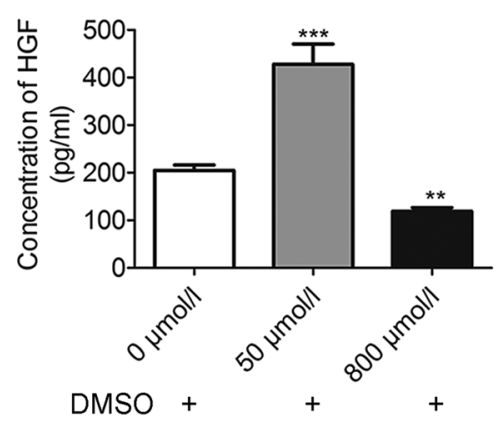

C

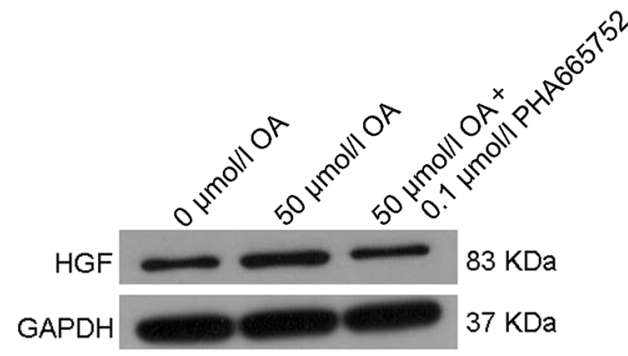

B
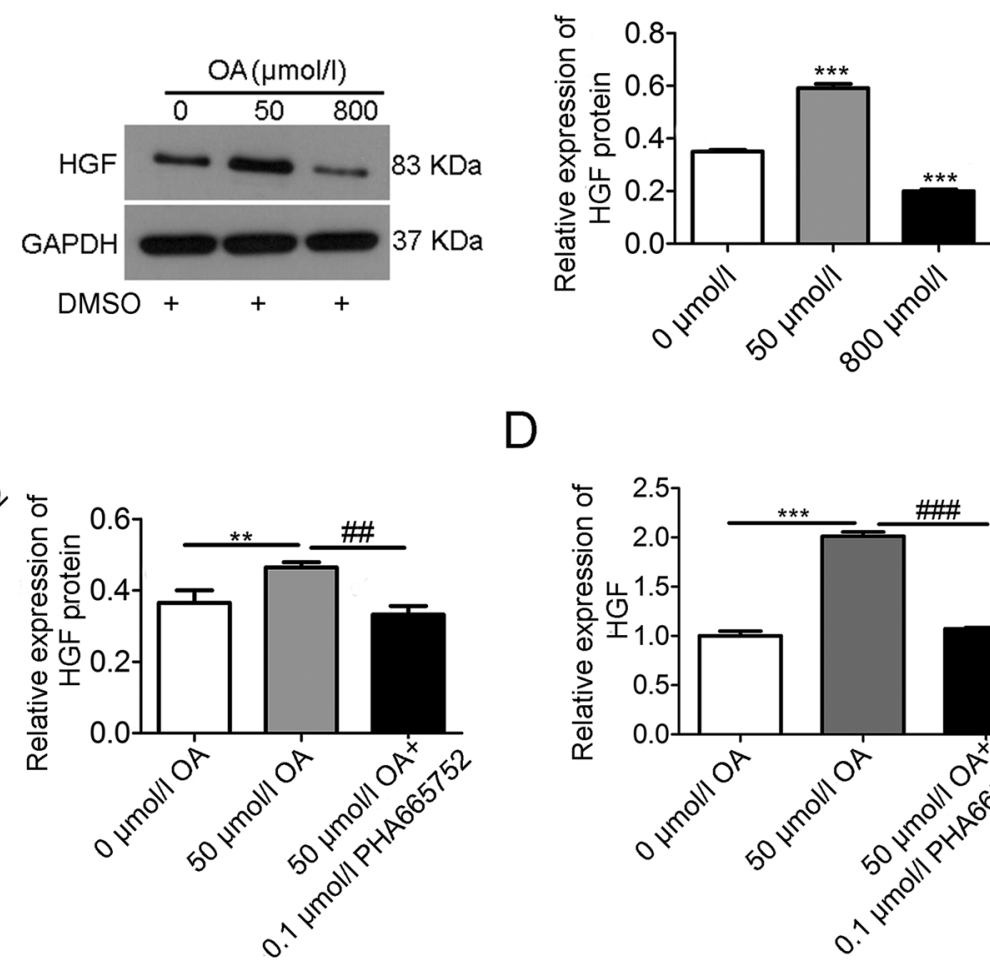

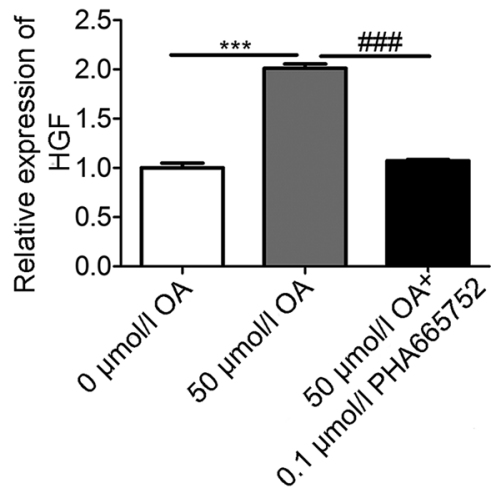

Figure 2. Effects of OA on the expression of HGF in A7r5 cells. (A) ELISA results at 24 h identified that low concentrations of OA (50 $\mu$ mol/1) upregulated the level of HGF, but HGF was downregulated at high concentrations ( $800 \mu \mathrm{mol} / 1)$ of OA. (B) Western blot analysis at $24 \mathrm{~h}$ demonstrated that low concentrations of $\mathrm{OA}(50 \mu \mathrm{mol} / \mathrm{l})$ increased the expression of HGF, but high concentrations of OA $(800 \mu \mathrm{mol} / \mathrm{l})$ downregulated this expression. (C) Western blot analysis showed that the increased HGF expression at low concentrations of OA $(50 \mu \mathrm{mol} / 1)$ was mitigated by PHA665752 (0.1 $\mu$ mol/1). (D) Reverse transcription-quantitative PCR analysis at $24 \mathrm{~h}$ indicated that the increased expression of HGF at low concentrations of OA $(50 \mu \mathrm{mol} / 1)$ was mitigated by PHA665752 (0.1 $\mu$ mol/1). Data are presented as the mean $\pm \mathrm{SD}(\mathrm{n}=3) .{ }^{* *} \mathrm{P}<0.01$ and ${ }^{* * * *} \mathrm{P}<0.001$ vs. $0 \mu \mathrm{M}$ OA group; ${ }^{\# \#} \mathrm{P}<0.01$ and ${ }^{\# \# \#} \mathrm{P}<0.001$ vs. $50 \mu$ mol/1 OA group. OA, oleic acid; HGF, hepatocyte growth factor.

(50 $\mu \mathrm{mol} / 1 \mathrm{OA})$ but downregulated it at high concentrations (800 $\mu \mathrm{mol} / 1 \mathrm{OA})$, as determined by ELISA (Fig. 2A) and western blotting (Fig. 2B). Moreover, the increased expression of $\mathrm{HGF}$ at low concentrations of $\mathrm{OA}(50 \mu \mathrm{mol} / \mathrm{l})$ was mitigated by $0.1 \mu \mathrm{mol} / 1$ PHA665752, as observed via western blotting (Fig. 2C) and RT-qPCR (Fig. 2D).

Effects of HGF inhibition and p38 MAPK inhibition on $O A$-induced A7r5 cell proliferation and migration. To investigate the mechanism of OA-induced A7r5 cell proliferation and migration via HGF signaling, the p38 inhibitor SB203580 was used, which inhibits PKB phosphorylation. The results demonstrated that the $\mathrm{A} 7 \mathrm{r} 5$ cell proliferation induced by $\mathrm{OA}$ (50 $\mu \mathrm{mol} / \mathrm{l})$ was mitigated by PHA665752 $(0.1 \mu \mathrm{mol} / \mathrm{l})$ or SB203580 (2 $\mu \mathrm{mol} / \mathrm{l})$ (Fig. 3A). Moreover, A7r5 cell migration was mitigated by SB203580 (2 $\mu \mathrm{mol} / \mathrm{l})$ (Fig. 3B). The effects of OA on p38 and p-p38 expression levels were then determined via western blotting (Fig. 3C), and the data revealed that OA treatment increased p-p38 expression at low concentrations (50 $\mu \mathrm{mol} / 1 \mathrm{OA})$ but downregulated it at high concentrations (800 $\mu \mathrm{mol} / \mathrm{l}$ OA). Moreover, the increased expression of $\mathrm{p}-\mathrm{p} 38$ at low concentrations of $\mathrm{OA}(50 \mu \mathrm{mol} / \mathrm{l})$ was mitigated by PHA665752 (0.1 $\mu \mathrm{mol} / \mathrm{l})$ (Fig. 3D) or SB203580 $(2 \mu \mathrm{mol} / \mathrm{l})$ (Fig. 3E). By contrast, there was no notable difference in the expression of $\mathrm{p} 38$.

In addition, via preliminary experiments, it was observed that $1 \mathrm{mmol} / 1 \mathrm{DMSO}, 2 \mu \mathrm{mol} / 1 \mathrm{SB} 203580$ or $0.1 \mu \mathrm{mol} / 1$
PHA665752 did not affect the proliferation and migration of A7r5 cells (data not shown), which was consistent with previous studies (29-34).

\section{Discussion}

The present study demonstrated that OA could promote A7r5 cell proliferation at a low concentration and over a short time length, but OA inhibited A7r5 cell proliferation at a high concentration and over longer times, as demonstrated using CCK-8 assays, cell cycle analysis and Transwell assays. Interestingly, the $\mathrm{A} 7 \mathrm{r} 5$ cell proliferation and migration induced by OA $(50 \mu \mathrm{mol} / \mathrm{l})$ were mitigated by PHA665752 $(0.1 \mu \mathrm{mol} / 1)$, a selective inhibitor of HGF. Using ELISA and western blotting, it was observed that HGF expression was increased in A7r5 cells at low doses of OA $(50 \mu \mathrm{mol} / \mathrm{l})$ but was decreased using high doses of OA $(800 \mu \mathrm{mol} / \mathrm{l})$. However, the increased expression of HGF induced by OA $(50 \mu \mathrm{mol} / \mathrm{l})$ was also mitigated by the HGF inhibitor PHA665752 (0.1 $\mu \mathrm{mol} / \mathrm{l})$.

$\mathrm{HGF}$, an angiogenic factor, is associated with the risk of coronary heart disease, stroke and atherosclerosis $(36,37)$. Circulating HGF has been proposed as a potential clinical biomarker for CVD (38). Previous studies have shown that high concentrations of HGF were significantly associated with the progression of atherosclerosis (39). HGF and its receptor c-MET serve an important role in endothelial injury and repair, angiogenesis, cell migration, cell survival and 
A

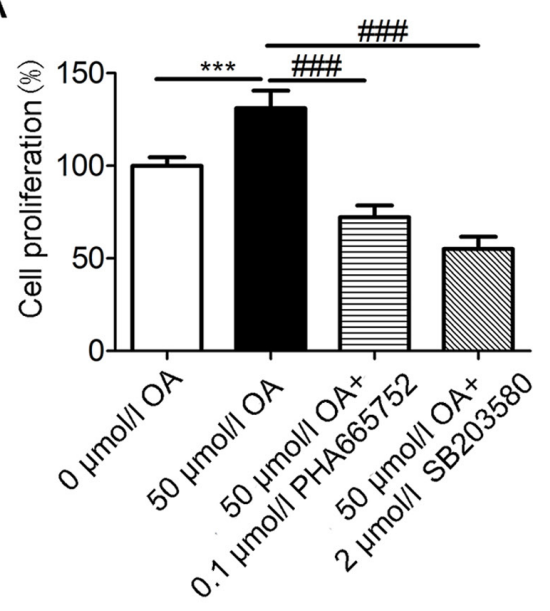

C
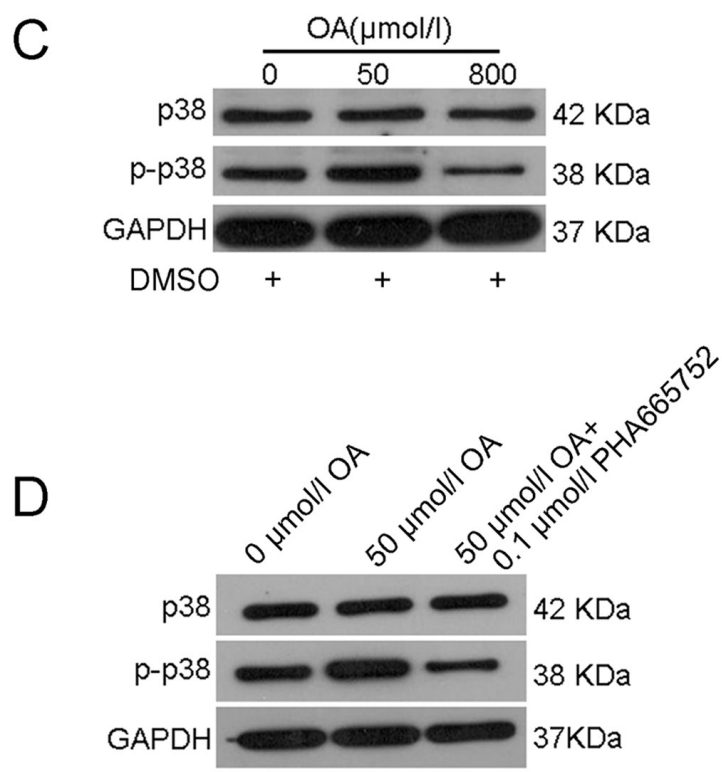

$E$

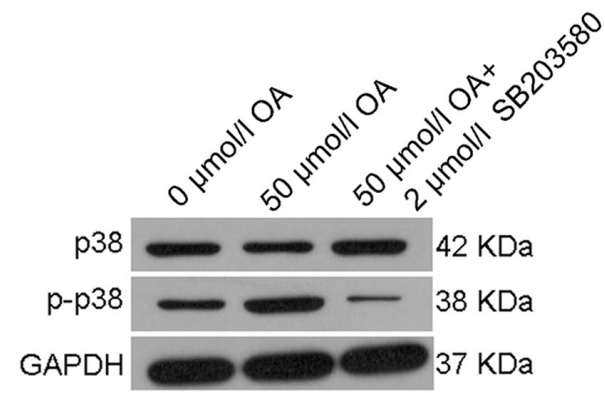

B

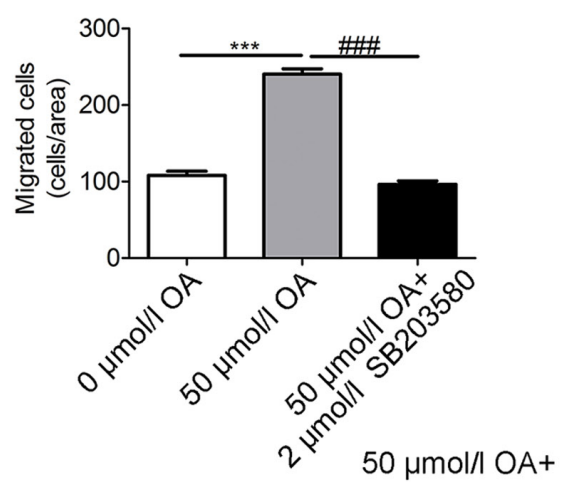

$0 \mu \mathrm{mol} / / \mathrm{OA} \quad 50 \mu \mathrm{mol} / \mathrm{lOA} 2 \mu \mathrm{mol} / / \mathrm{SB} 203580$
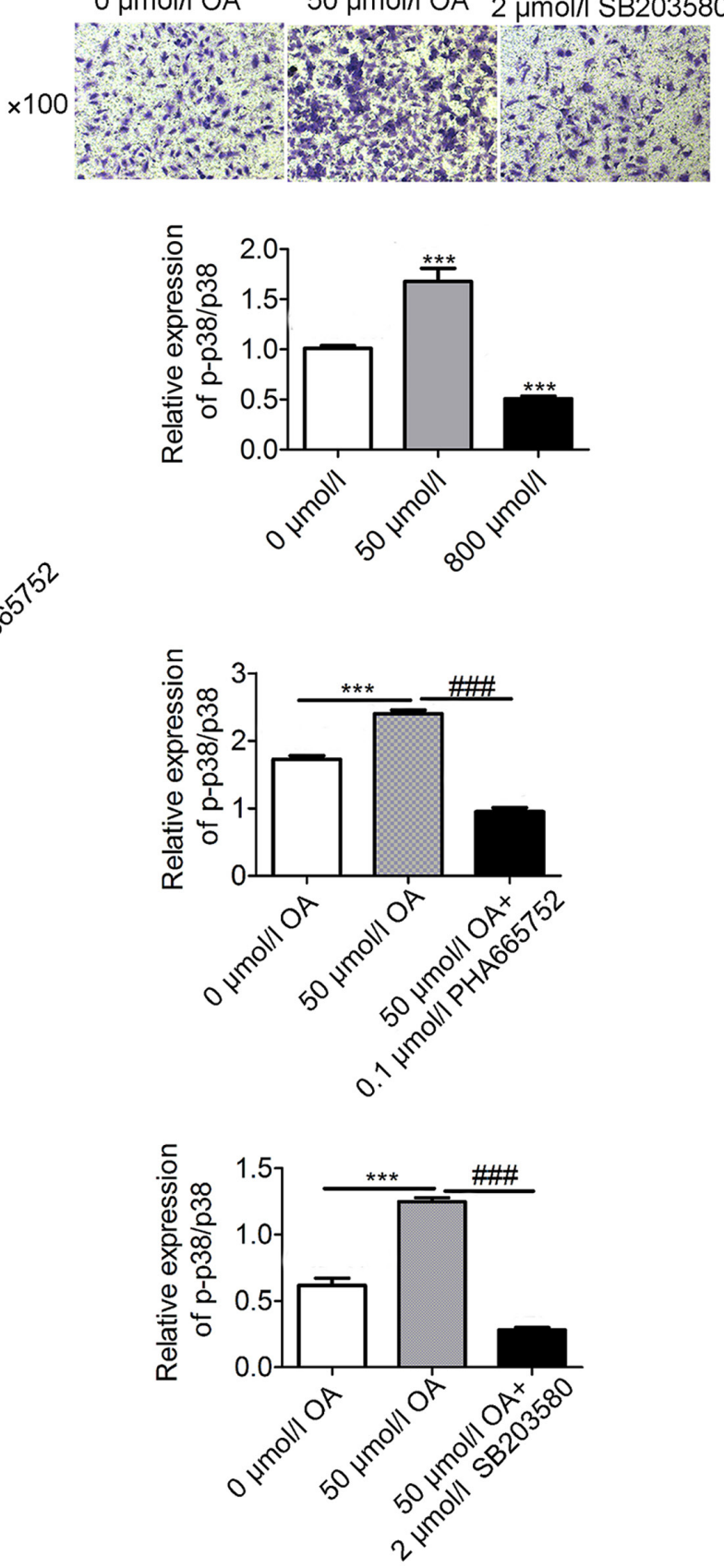

Figure 3. Effects of HGF inhibitors and p38 MAPK inhibitors on OA induced A7r5 cell proliferation and migration. (A) Cell Counting Kit-8 assays at $24 \mathrm{~h}$ indicated that the A7r5 cell proliferation induced by OA $(50 \mu \mathrm{mol} / 1)$ was significantly suppressed by PHA665752 (0.1 $\mu \mathrm{mol} / 1)$ or SB203580 (2 $\mu \mathrm{mol} / 1)$. (B) Cell migration with $50 \mu \mathrm{mol} / 1 \mathrm{OA}$ treatment for $24 \mathrm{~h}$ was mitigated by $2 \mu \mathrm{mol} / 1 \mathrm{SB} 203580$, a selective inhibitor of p38 MAPK. Magnification, x100. (C) Western blotting at $24 \mathrm{~h}$ showed that $\mathrm{OA}$ treatment increased p-p38 expression at low concentrations $(50 \mu \mathrm{mol} / \mathrm{l})$, but p-p38 expression was downregulated at high concentrations $(800 \mu \mathrm{mol} / \mathrm{l})$. (D) Western blotting at $24 \mathrm{~h}$ revealed that increased expression of p-p38 at low concentrations of OA (50 $\mu \mathrm{mol} / \mathrm{l})$ was mitigated by PHA665752 $(0.1 \mu \mathrm{mol} / \mathrm{l})$. (E) Western blot analysis at $24 \mathrm{~h}$ demonstrated that increased expression of p-p38 at low concentrations of OA (50 $\mu \mathrm{mol} / \mathrm{l})$ was mitigated by SB203580 $(2 \mu \mathrm{mol} / 1)$. Data are presented as the mean $\pm \mathrm{SD}(\mathrm{n}=3) .{ }^{* * *} \mathrm{P}<0.001 \mathrm{vs} .0 \mu \mathrm{M}$ OA group; ${ }^{\# \# ~} \mathrm{P}<0.001 \mathrm{vs}$. $50 \mu \mathrm{mol} / 1 \mathrm{OA}$ group. OA, oleic acid; p-, phosphorylated. 
anti-inflammatory responses in multiple cell types $(16,40)$. The present study used the HGF inhibitor PHA665752 $(27,41,42)$ to examine whether there was an association between the effect of OA and the HGF signaling pathway. The current results suggested that the effect of OA on proliferation and migration in A7r5 cells was mitigated by PHA665752. Moreover, the mRNA and protein expression levels of HGF induced by OA were suppressed by PHA665752 in A7r5 cells. These results indicated that $\mathrm{OA}$ promoted cell proliferation and migration via HGF signal transduction, which is helpful for further understanding the effects and mechanisms driving OA's effect on CVD (38).

p38 MAPK signaling has been reported to serve a role in VSMC proliferation (23) and HGF secretion from human astrocytoma cells (25). The present study used the p38 MAPK inhibitor SB203580 to evaluate whether there was an association between the effects of OA and p38 MAPK signaling, and p38 MAPK served as the positive control for several of the assays. The current data demonstrated that A7r5 cell proliferation and migration induced by $\mathrm{OA}(50 \mu \mathrm{mol} / \mathrm{l})$ were suppressed by SB203580 (2 $\mu \mathrm{mol} / 1)$, and the increased expression level of p-p38 at low concentrations of OA (50 $\mu \mathrm{mol} / \mathrm{l})$ was also mitigated by PHA665752 $(0.1 \mu \mathrm{mol} / \mathrm{l})$ or SB203580 (2 $\mu \mathrm{mol} / \mathrm{l})$. However, there was no notable difference in the expression level of p38. The present findings suggested that the effect of OA on cell proliferation and migration was mitigated by SB203580 in A7r5 cells, and the expression of p-p38 protein induced by OA was also suppressed by SB203580 in A7r5 cells. Furthermore, the results indicated that $\mathrm{OA}$ promoted cell proliferation and migration by regulating $\mathrm{p} 38$ phosphorylation, and that p38 MAPK signal transduction may serve an important role in the VSMC proliferation and migration induced by OA. Collectively, these data suggested that the OA-induced stimulation of the proliferation and migration of VSMCs may be associated with increased expression levels of HGF and p-p38. Therefore, the results of other studies $(19,23)$ and the present study support the hypothesis that p38 MAPK, as a downstream mediator, regulates the activity of HGF induced by $\mathrm{OA}$ in A7r5 cells.

The aforementioned results support the following two principal findings. First, low (physiological) concentrations of OA induce VSMC proliferation and migration, which is consistent with previous studies $(43,44)$. Second, the proliferation and migration of VSMCs induced by OA appear to be mediated by HGF and the p38 MAPK pathway. To the best of our knowledge, the current study demonstrated for the first time that $\mathrm{OA}$ stimulated the proliferation and migration of VSMCs via the HGF and p38 MAPK pathways in vitro.

Several signaling pathways, including the PI3K/Akt (28), reactive oxygen species (ROS) (45), AMP-activated protein kinase (AMPK)/endothelial nitric oxide synthase/FAS (46) and AMPK pathways (47), have been reported to serve a role in the proliferation and migration of VSMCs. The present findings suggest that HGF and p38 MAPK represent a new signaling pathway that participates in the proliferation and migration of VSMCs stimulated by OA.

The present study also suggested that the effect of OA on the proliferation and migration of A7r5 cells could be regulated by the HGF and p38 MAPK signaling pathways, and the proliferation and migration of VSMCs induced by OA were associated with increased expression levels of HGF and p-p38.

Several studies have revealed that OA treatment can induce apoptosis in neuronal cells (48), carcinoma cells (49) and VSMCs $(50,51)$, and is respectively associated with dephosphorylation of Bad, increasing ROS production, or caspase 3 activity, autophagy and LOX-1 upregulation. These results may explain the toxicity or inhibition of treatment with $\mathrm{OA}$ at high concentrations and over longer time frames on the proliferation and migration of A7r5 cells, which was observed in the current experiments. There are five limitations to the present study. First, the mechanisms involved in the up- or downregulation of the expression levels of HGF and p-p38 in A7r5 cells induced by OA need to be studied in the future. Second, the effects on cell cycle markers using small interfering RNAs or short hairpin RNAs, and other related signaling molecules, need to be evaluated further. Third, the present data indicated that OA had an effect on both the proliferation and migration of A7r5 cells, but the results of migration experiments may have been affected by differentiated proliferation (52). Fourth, the expression levels of contractile and synthetic markers in VSMCs should be evaluated. Fifth, there was the absence of PHA665752 or SB203580 alone control groups in this study.

In conclusion, the effect of $\mathrm{OA}$ on $\mathrm{A} 7 \mathrm{r} 5$ cell proliferation and migration was both time- and concentration-dependent, and low concentrations and short time frames promoted cell proliferation and migration, while high concentrations and long time frames inhibited cell proliferation and migration. Treatment with OA at $24 \mathrm{~h}$ could promote A7r5 cell proliferation and migration, but the effect of OA in promoting cell proliferation and migration disappeared at $48 \mathrm{~h}$, which was consistent with, but not precisely replicated, in our prior experiments $(12,13)$. These findings suggested that the promoting or inhibiting effects of glyceryl trioleate and medium chain TG on the proliferation of A7r5 cells (low concentrations and short time periods promoting cell proliferation; high concentrations and long time periods inhibiting cell proliferation) were not associated with cell apoptosis. Our previous findings $(12,13)$ are indirectly supported by a study from Belal et al (53), which revealed that OA can promote the proliferation of bovine satellite cells without apoptosis or necrosis. Oxidative stress and ROS production may explain the current experiment results obtained from treatment with OA for $48 \mathrm{~h}$ or at high concentrations (49), and long treatment durations or high concentrations of OA treatment may activate the MAPK pathway by oxidative stress to inhibit cell proliferation $(19,20)$. Collectively, it was indicated OA, HGF and p38 MAPK may be potential therapeutic targets for CVDs (such as atherosclerosis) (37). The present results provide novel insights into the biological effects of OA, HGF and p38 MAPK, and new evidence for the effect and mechanism of OA regulation on the proliferation and migration of VSMCs.

\section{Acknowledgements}

Not applicable. 


\section{Funding}

This work was partly supported by grant (grant no. jsdxrcyjkyxm201304) from the Jishou University and a grant (grant no. CX2018B711) from the Education Bureau of Hunan Province, China.

\section{Availability of data and materials}

The datasets used and/or analyzed during the current study are available from the corresponding author on reasonable request.

\section{Authors' contributions}

MY conceived and designed the study. JL performed the experiments and acquired the data. MY and JL confirm the authenticity of all the raw data. MY, JL and TC analyzed the data. MY, JL and TC drafted of the manuscript. MY and TC contributed to the critical revision of the manuscript for important intellectual content. All authors read and approved the final manuscript.

\section{Ethics approval and consent to participate}

Not applicable.

\section{Patient consent for publication}

Not applicable.

\section{Competing interests}

The authors declare that they have no competing interests.

\section{References}

1. Zhao WH, Zhang J, You Y, Man QQ, Li H, Wang CR, Zhai Y, Li Y, Jin SG and Yang XG: Epidemiologic characteristics of dyslipidemia in people aged 18 years and over in China. Zhonghua Yu Fang Yi Xue Za Zhi 39: 306-310, 2005 (In Chinese).

2. Després JP and Lemieux I: Abdominal obesity and metabolic syndrome. Nature 444: 881-887, 2006.

3. Xie C, Wang ZC, Liu XF and Yang MS: The common biological basis for common complex diseases: Evidence from lipoprotein lipase gene. Eur J Hum Genet 18: 3-7, 2010.

4. Hardy S, Langelier Y and Prentki M: Oleate activates phosphatidylinositol 3-kinase and promotes proliferation and reduces apoptosis of MDA-MB-231 breast cancer cells, whereas palmitate has opposite effects. Cancer Res 60: 6353-6358, 2000.

5. Sargsyan E, Artemenko K, Manukyan L, Bergquist J and Bergsten P: Oleate protects beta-cells from the toxic effect of palmitate by activating pro-survival pathways of the ER stress response. Biochim Biophys Acta 1861: 1151-1160, 2016.

6. Ross R: The pathogenesis of atherosclerosis - an updata. N Engl J Med 314: 488-500, 1986.

7. Basatemur GL, Jørgensen HF, Clarke MCH, Bennett MR and Mallat Z: Vascular smooth muscle cells in atherosclerosis. Nat Rev Cardiol 16: 727-744, 2019.

8. Bennett MR, Sinha S and Owens GK: Vascular smooth muscle cells in atherosclerosis. Circ Res 118: 692-702, 2016.

9. Zhou XX, Zhou XH, Yang HM and Su PQ: High triglyceride serum promotes the proliferation of vascular smooth muscle cells. Chin J Cardiol 28: 316, 2000 (In Chinese). doi:10.3760/ j:issn:0253-3758.2000.04.024.

10. Yin Z, Gao HK, Li LS, Luan RH and Wang HC: Effects of atorvastatin on hyperlipemic serum induced proliferation of vascular smooth muscle cells in rats. Chin Hear J 20: 180-183, 2008 (In Chinese).
11. Mattern HM and Hardin CD: Vascular metabolic dysfunction and lipotoxicity. Physiol Res 56: 149-158, 2007.

12. Wang YQ and Yang MS: Effects of glyceryl trioleate on the proliferation of rat aortic smooth muscle cells. J Chongqing Med Univ 39: 1384-1390, 2014 (In Chinese).

13. Yang MS and Wang YQ: Bidirectional effects of medium chain triglyceride on the proliferation of vascular smooth muscle cells. Chin J Arterioscler 24: 551-556, 2016 (In Chinese). doi: $10.13406 /$ jenki.cyxb.001052.

14. Liotti A, Cosimato V, Mirra P, Calì G, Conza D, Secondo A, Luongo G, Terracciano D, Formisano P, Beguinot F, et al: Oleic acid promotes prostate cancer malignant phenotype via the G protein-coupled receptor FFA1/GPR40. J Cell Physiol 233: 7367-7378, 2018

15. Yang C, Lim W, Bazer FW and Song G: Oleic acid stimulation of motility of human extravillous trophoblast cells is mediated by stearoyl-CoA desaturase-1 activity. Mol Hum Reprod 23: 755-770, 2017.

16. Nakamura T, Sakai K, Nakamura T and Matsumoto K: Hepatocyte growth factor twenty years on: Much more than a growth factor. J Gastroenterol Hepatol 26 (Suppl 1): S188-S202, 2011.

17. Forte G, Minieri M, Cossa P, Antenucci D, Sala M, Gnocchi V, Fiaccavento R, Carotenuto F, De Vito P,Baldini PM, et al: Hepatocyte growth factor effects on mesenchymal stem cells: Proliferation, migration, and differentiation. Stem Cells 24: 23-33, 2006.

18. Greene EL, Lu G, Zhang D and Egan BM: Signaling events mediating the additive effects of oleic acid and angiotensin II on vascular smooth muscle cell migration. Hypertension 37: 308-312, 2001.

19. Wan Q, Liu Z and Yang Y: Puerarin inhibits vascular smooth muscle cells proliferation induced by fine particulate matter via suppressing of the p38 MAPK signaling pathway. BMC Complement Altern Med 18: 146, 2018.

20. Kyriakis JM and Avruch J: Mammalian MAPK signal transduction pathways activated by stress and inflammation: A 10-year update. Physiol Rev 92: 689-737, 2012.

21. Cuenda A and Rousseau S: p38 MAP-kinases pathway regulation, function and role in human diseases. Biochim Biophys Acta 1773: 1358-1375, 2007.

22. Karin M and Gallagher E: From JNK to pay dirt: Jun kinases, their biochemistry, physiology and clinical importance. IUBMB Life 57: 283-295, 2005.

23. Jacob T, Ascher E, Alapat D, Olevskaia Y and Hingorani A: Activation of p38MAPK signaling cascade in a VSMC injury model: Role of p38MAPK inhibitors in limiting VSMC proliferation. Eur J Vasc Endovasc Surg 29: 470-478, 2005.

24. Awasthi V and King RJ: PKC, p42/p44 MAPK, and p38 MAPK are required for HGF-induced proliferation of H441 cells. Am J Physiol Lung Cell Mol Physiol 279: L942-L949, 2000.

25. Chattopadhyay N, Tfelt-Hansen J and Brown EM: PKC, p42/44 MAPK and p38 MAPK regulate hepatocyte growth factor secretion from human astrocytoma cells. Brain Res Mol Brain Res 102: 73-82, 2002.

26. Yao J, Ke J, Zhou Z, Tan G, Yin Y, Liu M, Chen J and Wu W: Combination of HGF and IGF-1 promotes connexin 43 expression and improves ventricular arrhythmia after myocardial infarction through activating the MAPK/ERK and MAPK/p38 signaling pathways in a rat model. Cardiovasc Diagn Ther 9: 346-354, 2019.

27. Christensen JG, Schreck R, Burrows J, Kuruganti P, Chan E, Le P, Chen J, Wang X, Ruslim L, Blake R, et al: A selective small molecule inhibitor of c-Met kinase inhibits c-Met-dependent phenotypes in vitro and exhibits cytoreductive antitumor activity in vivo. Cancer Res 63: 7345-7355, 2003.

28. Yun MR, Lee JY, Park HS, Heo HJ, Park JY, Bae SS, Hong KW, Sung SM and Kim CD: Oleic acid enhances vascular smooth muscle cell proliferation via phosphatidylinositol 3-kinase/Akt signaling pathway. Pharmacol Res 54: 97-102, 2006.

29. Qi W, Ding D and Salvi RJ: Cytotoxic effects of dimethyl sulphoxide (DMSO) on cochlear organotypic cultures. Hear Res 236: 52-60, 2008.

30. Xiang Q, Zhen Z, Deng DY, Wang J, Chen Y, Li J, Zhang Y, Wang F, Chen N, Chen H and Chen Y: Tivantinib induces G2/M arrest and apoptosis by disrupting tubulin polymerization in hepatocellular carcinoma. J Exp Clin Cancer Res 34: 118, 2015.

31. Sreekanth GP, Chuncharunee A, Sirimontaporn A, Panaampon J, Noisakran S, Yenchitsomanus PT and Limjindaporn T: SB203580 modulates p38 MAPK signaling and dengue virus-induced liver injury by reducing MAPKAPK2, HSP27, and ATF2 phosphorylation. PLoS One 11: e0149486, 2016. 
32. He T, Liu S, Chen S, Ye J, Wu X, Bian Z and Chen X: The p38 MAPK inhibitor SB203580 abrogates tumor necrosis factor-induced proliferative expansion of mouse $\mathrm{CD}^{+}{ }^{+} \mathrm{Foxp} 3^{+}$ regulatory T cells. Front Immunol 9: 1556, 2018.

33. Liu T, Li Q, Sun Q, Zhang Y, Yang H, Wang R, Chen L and Wang W: MET inhibitor PHA-665752 suppresses the hepatocyte growth factor-induced cell proliferation and radioresistance in nasopharyngeal carcinoma cells. Biochem Biophys Res Commun 449: 49-54, 2014

34. Xiang QF, Zhan MX, Li Y, Liang H, Hu C, Huang YM, Xiao J, He X, Xin YJ, Chen MS and Lu LG: Activation of MET promotes resistance to sorafenib in hepatocellular carcinoma cells via the AKT/ERK1/2-EGR1 pathway. Artif Cells Nanomed Biotechnol 47: 83-89, 2019.

35. Livak KJ and Schmittgen TD: Analysis of relative gene expression data using real-time quantitative PCR and the 2(-Delta Delta C(T)) method. Methods 25: 402-408, 2001

36. Bielinski SJ, Berardi C, Decker PA, Larson NB, Bell EJ, Pankow JS, Sale MM, Tang W, Hanson NQ, Wassel CL, et al: Hepatocyte growth factor demonstrates racial heterogeneity as a biomarker for coronary heart disease. Heart 103: 1185-1193, 2017.

37. Bell EJ, Larson NB, Decker PA, Pankow JS, Tsai MY, Hanson NQ, Wassel CL, Longstreth WT Jr and Bielinski SJ: Hepatocyte growth factor is positively associated with risk of stroke: The MESA (multi-ethnic study of atherosclerosis) Stroke 47: 2689-2694, 2016.

38. Gallo S, Sala V, Gatti S and Crepaldi T: Cellular and molecular mechanisms of $\mathrm{HGF} / \mathrm{Met}$ in the cardiovascular system. Clin Sci (Lond) 129: 1173-1193, 2015

39. Bell EJ, Decker PA, Tsai MY, Pankow JS, Hanson NQ, Wassel CL, Larson NB, Cohoon KP, Budoff MJ, Polak JF, et al: Hepatocyte growth factor is associated with progression of atherosclerosis: The multi-ethnic study of atherosclerosis (MESA). Atherosclerosis 272: 162-167, 2018.

40. Nakamura T and Mizuno S: The discovery of hepatocyte growth factor (HGF) and its significance for cell biology, life sciences and clinical medicine. Proc Jpn Acad Ser B Phys Biol Sci 86: 588-610, 2010

41. Smolen GA, Sordella R, Muir B, Mohapatra G, Barmettler A, Archibald H, Kim WJ, Okimoto RA, Bell DW, Sgroi DC, et al: Amplification of MET may identify a subset of cancers with extreme sensitivity to the selective tyrosine kinase inhibitor PHA-665752. Proc Natl Acad Sci USA 103: 2316-2321, 2006.

42. Mukohara T, Civiello G, Davis IJ, Taffaro ML, Christensen J, Fisher DE, Johnson BE and Jänne PA: Inhibition of the met receptor in mesothelioma. Clin Cancer Res 11: 8122-8130, 2005.

43. Lu G, Meier KE, Jaffa AA, Rosenzweig SA and Egan BM: Oleic acid and angiotensin II induce a synergistic mitogenic response in vascular smooth muscle cells. Hypertension 31: 978-985, 1998.
44. Lu G, Greene EL, Nagai T and Egan BM: Reactive oxygen species are critical in the oleic acid-mediated mitogenic signaling pathway in vascular smooth muscle cells. Hypertension 32: 1003-1010, 1998

45. Ahn HJ, Park J, Song JS, Ju MK, Kim MS, Ha H, Song KH and Kim YS: Mycophenolic acid inhibits oleic acid-induced vascular smooth muscle cell activation by inhibiting cellular reactive oxygen species. Transplantation 84: 634-638, 2007.

46. Ou TT, Lin MC, Wu CH, Lin WL and Wang CJ: Gallic acid attenuates oleic acid-induced proliferation of vascular smooth muscle cell through regulation of AMPK-eNOS-FAS signaling. Curr Med Chem 20: 3944-3953, 2013.

47. Lin MC, Ou TT, Chang $\mathrm{CH}$, Chan $\mathrm{KC}$ and Wang CJ: Protocatechuic acid inhibits oleic acid-induced vascular smooth muscle cell proliferation through activation of AMP-activated protein kinase and cell cycle arrest in G0/G1 phase. J Agric Food Chem 63: 235-241, 2015.

48. Zhu Y, Schwarz S, Ahlemeyer B, Grzeschik S, Klumpp S and Krieglstein J: Oleic acid causes apoptosis and dephosphorylates Bad. Neurochem Int 46: 127-135, 2005.

49. Carrillo C, Cavia Mdel M and Alonso-Torre SR: Antitumor effect of oleic acid; mechanisms of action: A review. Nutr Hosp 27: 1860-1865, 2012

50. Cheng CI, Lee YH, Chen PH, Lin YC, Chou MH and Kao YH: Free fatty acids induce autophagy and LOX-1 upregulation in cultured aortic vascular smooth muscle cells. J Cell Biochem 118: 1249-1261, 2017.

51. Artwohl M, Lindenmair A, Roden M, Waldhäusl WK, Freudenthaler A, Klosner G, Ilhan A, Luger A and Baumgartner-Parzer SM: Fatty acids induce apoptosis in human smooth muscle cells depending on chain length, saturation, and duration of exposure. Atherosclerosis 202: 351-362, 2009.

52. Zhang C, Wang W, Lin J, Xiao J and Tian Y: IncRNA CCAT1 promotes bladder cancer cell proliferation, migration and invasion. Int Braz J Urol 45: 549-559, 2019.

53. Belal SA, Sivakumar AS, Kang DR, Cho S, Choe HS and Shim KS: Modulatory effect of linoleic and oleic acid on cell proliferation and lipid metabolism gene expressions in primary bovine satellite cells. Anim Cells Syst (Seoul) 22: 324-333, 2018.

This work is licensed under a Creative Commons Attribution-NonCommercial-NoDerivatives 4.0 International (CC BY-NC-ND 4.0) License. 